\title{
Determinants of Female Sterilization in Brazil, 2001-2007
}

Ernesto F. L. Amaral and Joseph E. Potter

RAND Labor \& Population

WR-1093

February 2015

This paper series made possible by the NIA funded RAND Center for the Study of Aging (P3OAG012815) and the NICHD funded RAND Population Research Center (R24HD050906).

RAND working papers are intended to share researchers' latest findings and to solicit informal peer review. They have been approved for circulation by RAND Labor and Population but have not been formally edited or peer reviewed. Unless otherwise indicated, working papers can be quoted and cited without permission of the author, provided the source is clearly referred to as a working paper. RAND's publications do not necessarily reflect the opinions of its research clients and sponsors. RAND® is a registered trademark. 


\title{
Determinants of female sterilization in Brazil, 2001-2007
}

\author{
Ernesto F. L. Amaral \\ RAND Corporation \\ eamaral@rand.org \\ Joseph E. Potter \\ The University of Texas at Austin \\ joe@prc.utexas.edu
}

\begin{abstract}
This study aims to investigate the determinants of female sterilization in Brazil. The analysis is innovative because it adds the time of exposure to the risk of sterilization into survival models. The models control for postpartum duration, age at delivery, parity at delivery, type of delivery, place of delivery, region of residence at the time of interview, color/race, and years of schooling at the time of interview. Data is from the 2006 Brazilian National Survey on Demography and Health of Children and Women (PNDS). The strongest probability that sterilization might occur was observed among women who gave birth at private hospitals and received support from health insurance companies at childbirth. Female sterilization is also executed in combination with childbirth and cesarean section. The findings suggest years of schooling do not predict the risk of sterilization. The higher chances of getting sterilized among black women are specific to the public sector at higherorder postpartum duration (interval sterilization).
\end{abstract}

\section{Keywords}

Contraceptive Agents. Female. Sterilization. Reproductive Health. Brazil.

\section{Acknowledgments}

We gratefully acknowledge Kari White for her support to set up the databases and estimate the regression models. 


\section{Introduction}

In Brazil, there was an increase in the mean age of fertility from 26.3 years in 2000 to 26.8 years in 2010. Women between 20-24 years of age accounted for 27 percent of the fertility in 2010, but this percentage was 29.3 percent in 2000 . There is increased fertility participation for women above 30 years of age. The total fertility rate fell from 6.28 children per woman in 1960 to 5.76 in 1970, 4.35 in 1980, 2.85 in 1991, 2.38 in 2000, and to below the replacement level (1.90) in 2010. ${ }^{1}$ When dividing Brazil into regions, the TFR in 2010 was 2.47 in the North, 2.06 in the Northeast, 1.7 in the Southeast, 1.78 in the South, and 1.92 in the Central-West region. These regional differences had been found in previous studies. ${ }^{2,3}$

The increased use of modern contraception is a major factor associated with the decline of fertility in Brazil. ${ }^{4-8}$ Contraceptive methods are largely concentrated in the use of pills and female sterilization. ${ }^{8-11}$ The rise in the practice of contraception occurred in a context not associated to public policies on birth control. The government did not intervene in order to reduce fertility, change female reproductive behavior, or increase the use of contraception. ${ }^{12}$ Brazil has inadequate public services for sexual and reproductive health, characterized by excessive "medicalization," the predominance of the private sector, delayed access to contraceptives, inappropriate use of contraceptives, a lack of medical care and reversible methods, a high proportion of unwanted pregnancies, and social inequality effecting access to contraception. ${ }^{11,13-17}$ In recent decades, there has been an expansion on the use of modern contraceptive methods. ${ }^{8,18,19}$

From 1996 to 2006, Brazil experienced a change in the distribution of married and cohabiting women between 15-44 years of age by type of contraceptive use. Female sterilization remained used by 25.9 percent of these women in 2006 , compared to 38.5 percent in 1996 . Women who use pills rose from 23.1 percent in 1996 to 27.4 percent in 2006. A total of 22.1 percent of women did not use any method in 1996 . This rate fell to 18.4 percent in 2006 . The use of condoms increased from 4.6 to 13 percent during the period. The percentage of women who were married to men who had obtained a vasectomy rose from 2.8 to 5.1 percent during this period. The practice of withdrawal decreased from three to 2.1 percent, and women who utilized periodic abstinence fell from 2.9 to one percent. The use of other methods (IUD, diaphragm, injections, etc.) rose from three to seven percent throughout the same period. ${ }^{8}$

The federal government implemented the family planning law in $1997 .{ }^{20}$ One of the goals of the law was to enable sterilization in public hospitals, but with restrictions for surgeries during cesarean deliveries, childbirth, and abortion. The law \#9,263 from January 12, 1996 (article 10 vetoed until 
August 19, 1997) expresses that: "The surgical sterilization of women is forbidden during childbirth or abortion, except for health reasons caused by previous successive cesarean deliveries. ${ }^{, 20}$ Despite these legal impediments, female sterilization is still held in conjunction with childbirth and cesarean section. ${ }^{4,21-25}$ Furthermore, the law institutes that female and male sterilizations are permitted only for those above 25 years of age or with at least two children born alive. Sterilization may be performed no less than 60 days from the request, with the intention to allow counseling by a public multidisciplinary health group, as well as to avoid sterilization at early ages.

There are several studies that identify evidence of regret following a female sterilization procedure. $^{8,11,26-32}$ There is also evidence of a frustrated demand for female sterilization. ${ }^{33-38}$ Municipalities have insufficient public infrastructure and human resources to supply female sterilization, and the regulations of the 1997 law restrain the provision of this surgical procedure. ${ }^{36}$ Extreme inequality in the access to female sterilization exists between the public and private sectors. ${ }^{34}$ A large percentage of unnecessary cesarean deliveries are being utilized as a way for women to obtain access to sterilization. Since sterilization is harder to get at the public sector, women might be going to the private sector in order to get this procedure, in conjunction with a cesarean delivery. ${ }^{21,24,33-37}$

Female sterilization is more prevalent among women at older cohorts, with higher parity, with fewer years of education, with less educated spouses or companions, and among black and indigenous people. ${ }^{18}$ Women with high levels of education get sterilized after they reach their ideal number of children as a result of planning for a specific number of offspring through the use of temporary contraceptives. Poorly educated women get sterilized without having used another contraceptive method, after reaching more than the ideal number of children while experiencing shorter birth intervals, demonstrating an increased incidence of regret for the total number of children ever born. ${ }^{8}$ The option for sterilization seems to be a result of higher fertility among women who started childbearing early in life. ${ }^{39}$

Previous studies that evaluated the risk of female sterilization included information about marital status (married, cohabiting/in union, not in union) into the analysis, as these women tend to spend a great proportion of their lives outside of marriage or in less stable unions. ${ }^{40}$ Other studies also controlled their estimates by the number of unions experienced by women. ${ }^{5}$ Differentials in the risk of sterilization can take into account the type of delivery (vaginal birth or cesarean section). Despite all these studies, there is still a need to deepen the knowledge about female sterilization in Brazil. Between 2000 and 2010, the main public health and medical journals available in the Scientific 
Electronic Library Online (SciELO) published only 31 papers about female sterilization out of 6,061 publications. $^{41}$

The study of female sterilization is important to the area of reproductive health in Brazil. (1) 25.9 percent of married or cohabiting women between 15 and 44 years of age were sterilized in 2006. (2) There are legal requirements related to the access of female sterilization. (3) Sterilization is an irreversible contraceptive method. (4) The availability of sterilization is associated with type and place of birth. (5) There is evidence of regret after sterilization. (6) There is an indication of a frustrated demand for sterilization. (7) The public services for sexual and reproductive health are inadequate in the country.

The objective of this study is to investigate the determinants of female sterilization in Brazil between January 2001 and July 2007. This analysis seeks to comprehend the effects of different birth intervals (postpartum duration) on the risk of a woman getting sterilized. The study is not limited to a cross-sectional investigation. The data is organized by postpartum duration, in order to estimate the risks of sterilization at childbirth (zero months), as well as the risks of interval sterilization (1, 2, 3-6, 7-12, 13-18, 19+ months). The main hypothesis is that the significant effects of color/race and years of schooling from previous studies are a result of higher exposed risks to undergo a sterilization procedure among women with higher fertility rates (black and lower educated). When person months of exposure is taken into account, the effects of color/race and years of schooling are expected to lose significance. In order to conduct this exercise, estimates are controlled by a series of characteristics of women. In the next section, the data and methodological strategies are explained. Then, main results are presented and the last section has a discussion of the findings.

\section{Data and methods}

The data is from the 2006 Brazilian National Survey on Demography and Health of Women and Children (PNDS). The analysis includes women between 15-49 years of age at the time of the interview, who had experienced live births beginning in January 2001. Data comes from questionnaires with information on households/individuals $(n=56,365)$, women $(n=15,575)$, history of pregnancies $(n=6,833)$, and history of children born alive $(n=27,477)$. By aggregating variables from different databases, the unit of analysis reports on pregnancies between January 2001 and July 2007, because the histories of pregnancies and children born alive were collected for this specific period. 
Information on the contraceptive method that women were currently using includes traditional and modern methods. There is information on the month and year that the female sterilization took place. Information that identifies the month and year of a birth, as well as the duration of the pregnancy, enable the estimation of the moment of conception. The database about children born alive has information on pregnancy and childbirth, including place of delivery and type of delivery. Information about the households/individuals, such as date of birth and years of schooling was also collected from the database. A sterilized woman with multiple pregnancies during the period is marked as sterile only following the last pregnancy. Based on the date of birth of each woman, date of sterilization and date of delivery/childbirth, it is possible to estimate the age of each women at the time of sterilization, as well as their age at the time of each delivery. The number of children ever born (parity) at the time of each delivery is calculated based on the current parity and the birth order (month and year of each delivery).

The date of interview, date of sterilization, and date of delivery/childbirth are transformed into time in months: 1 (January 2001) to 79 (July 2007). The time of conception is the time of delivery minus the duration of pregnancy. The time of the subsequent conception is also estimated. The initial time of exposure to the risk of sterilization equals the time of delivery/childbirth less one unit, in order to include sterilizations that occurred during the month of birth. The final time of exposure to the risk of sterilization equals the time of interview, the time of next conception (for non-sterilized women), or the time of sterilization.

Proportional hazards (PH) models estimate the risk of women getting sterilized. ${ }^{5,40,42-45}$ Several parametric models make strong assumptions about the shape of the hazard function. The Cox model makes no assumptions. In the present paper, semi-parametric hazards are estimated. More specifically, piece-wise constant exponential models are fitted, which uses a continuous time modeling framework. The hazard is assumed to be constant within pre-specified survival time intervals. However, the constant may differ for different intervals. The hazard function $\left[h\left(t_{i j}\right)\right]$ assesses the risk at a particular moment that an individual who has not yet done so will experience the target event. This function is the instantaneous rate of occurrence of the event at time $t_{j}$ for an individual $i$. The numerator of the hazard function is the conditional probability that the event will occur in a specific interval given that it has not occurred before, and the denominator is the interval width $(\Delta t)$. The division of one by the other originates a rate of event occurrence per unit of time. The probability of observing any particular event time is infinitesimally small. In continuous time, the probability that an event will occur at any specific instant approaches zero. The continuous-time hazard for an individual $i$ at time $t_{j}$ is: ${ }^{46}$ 
$h\left(t_{i j}\right)=$ limit as $\Delta t \rightarrow 0\left\{\frac{\operatorname{Pr}\left[T_{i} \text { is in the interval }\left(t_{j}, t_{j}+\Delta t \mid T_{i} \geq t_{j}\right)\right]}{\Delta t}\right\}$.

This specification can be generalized to have a constant hazard within each interval along the survival time axis. In order to accomplish this exercise, the data is reorganized to create some timevarying covariates. Variables are generated to allow the constant term in the hazard regression to differ from interval to interval. The baseline hazard may differ over seven postpartum duration intervals (in months) that a woman was exposed to the risk of sterilization $(0,1,2,3-6,7-12,13-$ $18,19+)$. One time indicator is created for each interval $J$, as seven dummy variables $\left(D_{J}\right)$, to link the episodes in the reorganized data with these time intervals. A set of $P$ substantive predictors $\left(X_{P}\right)$ is generated, as individual characteristics, which generate a vector of regression coefficients $\left(\beta_{P}\right)$ :

$\operatorname{logit} h\left(t_{j}\right)=\left[\alpha_{0} D_{0}+\alpha_{1} D_{1}+\alpha_{2} D_{2}+\alpha_{3-6} D_{3-6}+\alpha_{7-12} D_{7-12}+\alpha_{13-18} D_{13-18}+\alpha_{19+} D_{19+}\right]+\left[\beta_{1} X_{1}+\ldots+\beta_{P} X_{P}\right]$.

This equation eliminates the subscript $i$ for individuals, because its presence is implicit. Moreover, this representation excludes the subscript $j$ for time periods from the right side of the equation, because it is either redundant (for the time indicators) or implicit (for the substantive predictors). ${ }^{46}$ All seven duration intervals could be included as covariates if the constant term is excluded, as in Equation (2). However, the constant term is included and one interval is taken as the reference category (zero months). This option allows a direct interpretation of how the baseline hazards for the six remaining intervals differ from the reference interval. These two forms of estimation are similar and they would generate the same predicted values. The regression tables show exponential of coefficients $\left[\exp \left(\beta_{P}\right)\right]$, known as hazard ratios.

The cumulative hazard function $\left[H\left(t_{i j}\right)\right]$ assesses, at each point in time, the total amount of accumulated risk that individual $i$ has faced from the beginning of time until the present. The cumulative hazard for an individual $i$ at time $t_{j}$ is defined as: ${ }^{46}$

$H\left(t_{i j}\right)=$ cumulation between $t_{0}$ and $t_{j}\left[h\left(t_{i j}\right)\right]$.

The term "cumulation between $t_{0}$ and $t_{j}$ " indicates that cumulative hazard totals the infinite number of specific values of $h\left(t_{i j}\right)$ that exist between $t_{0}$ and $t_{j}$. Thus the cumulative hazard or cumulative risk is the sum of the risks someone faces going from duration 0 to time $t_{j}$, given a vector of individual characteristics $\left(X_{P}\right)$. 
A set of graphs illustrates cumulative predicted hazards (cumulative probabilities of getting sterilized). The cumulative hazard has to take into account the width of each postpartum interval ( 0 , 1, 2, 3-6, 7-12, 13-18, 19+). More specifically, the first three postpartum durations $(0,1$, and 2) have widths equal to one month. The 3-6 postpartum interval has a width equal to four months. The 7-12 and 13-18 intervals have widths equal to six months. The last interval (19+) has a width equal to 61 months, which is the observed width for the entire sample in this interval (19 months through 79 months).

The steps for statistical modeling are the following: (1) establish the sample design (strata and conglomerate) and the expansion factor of women (weight) with the "svyset" command in Stata. The strata are the combination of the five major regions (North, Northeast, Southeast, Central-West, and South) and household situation (urban and rural). The primary sampling unit (PSU) is formed by the census tracts (conglomerate); (2) indicate that this study is based on a survival analysis, with starting and ending times of exposure to the risk of sterilization, as well as note the sterilization event, with the "stset" command. This initial database utilizes pregnancies as the unit of analysis; (3) organize the database with postpartum duration (in months) as the unit of analysis by disaggregating pregnancies into the different times that a woman was at the risk of getting sterilized. Every pregnancy was disaggregated into units of analysis that indicate the exposure of women to a specific postpartum duration. This procedure allows us to check the effects of the time of the exposure of women after delivery/childbirth (postpartum duration) to the event of sterilization. The time of delivery/childbirth (in months) is used to determine the postpartum duration that a woman was exposed to the risk of sterilization: $0,1,2,3-6,7-12,13-18,19+$. The computer software compares the initial time of exposure to the risk of sterilization (postpartum period) with the final time of exposure (already calculated) to define how many times each pregnancy will be disaggregated in the database. The "stsplit" command disaggregates the unit of analysis (pregnancy) into the different times that a woman entered the next postpartum period and was exposed to the risk of sterilization. The initial time of exposure is recalculated, considering the final time of the preceding postpartum period for each woman; (4) indicate, once again, that this study is based on a survival analysis, but now with the ending time of the postpartum period ("stset" command); and (5) estimate piece-wise constant exponential regression models, in order to understand the effect of postpartum periods and other independent variables on the risk of female sterilization, with the "svy: streg, d(exp)" command. These models are estimated using the exponential distribution. 
The final database has a total of 4,580 women with live births between January 2001 and July 2007. The initial database had a total of 5,890 pregnancies that resulted in live births with valid information for all variables of interest. Models include only one observation for cases of multiple births. Women who did not remember their own date of birth, date of sterilization, or date of delivery/childbirth were also excluded from the analysis. The estimates exclude women who gave birth in health centers, since none of them were sterilized. Women with deliveries at home were also removed from the analysis, because they are not at risk of getting sterilized. Women with one child ever born at the time of delivery were not included in the models, because of their small likelihood to get sterilized. The database was disaggregated into postpartum duration as the unit of analysis, which includes 17,376 observations, related to 3,398 pregnancies (births), and 2,762 women (cases).

Information on female sterilization is used as the dependent variable, considering the month and year of sterilization. The independent variables used to explain the risk of female sterilization are the following. (1) Postpartum duration in months (0, 1, 2, 3-6, 7-12, 13-18, 19+). (2) Woman's age in years at time of delivery (15-24, 25-29, 30-34, 35-49). (3) Parity at delivery $(2,3,4+)$, calculated with information about number of children ever born and birth order. (4) Place of delivery: public hospital (SUS), health insurance ("convênio"), and private hospital. (5) Region of residence: North, Northeast, Southeast, Central-West, and South. (6) Color/race of the woman: white ("branca"), black ("preta”), brown ("parda"), yellow/Asian ("amarela"), and indigenous ("indigenous"). (7) Years of schooling: 0-3 (less than first phase of elementary school), 4-7 (from completed first phase of elementary school to less than second phase of elementary school), 8-10 (from completed second phase of elementary school to less than secondary school), and 11+ (from completed secondary school and above). Information on region of residence and years of schooling might change over time. However, the database does not provide for this variation, but only addresses the situation at the time of the interview.

Previous models that evaluated the risk of female sterilization included information about marital status (married, cohabiting/in union, not in union) into the analysis, as these women tend to spend a great proportion of their lives outside of marriage or in less stable unions. ${ }^{40}$ Other studies also controlled their estimates by the number of unions experienced by women. ${ }^{5}$ However, information on marital status and number of marriages/unions are not included in the analysis, since they might introduce problems of endogeneity into the regression models. A total of 100 women reported male sterilization as their form of contraception. However, the date that the vasectomy occurred is not 
available in the database. Therefore, the models do not estimate the impact of vasectomy on the risk of female sterilization, despite the significance of male contraception. ${ }^{47,48}$

A series of models estimate the risk of female sterilization. Some models take into account only cases concerning cesarean section or vaginal birth, in order to verify differentials in the risk of sterilization by type of delivery. Woman who want to get sterilized give birth at the private sector in order to have access to this procedure following a cesarean delivery. ${ }^{21,24,33-37}$

Five models illustrate the results. The first three models include the main effects of all independent variables and are related to: (1) all observations in the sample; (2) subset of the sample with observations related to cesarean section; and (3) subset related to vaginal delivery observations. These models include the independent variables mentioned above, which are based on previous studies: postpartum duration, age at delivery, parity at delivery, place of delivery, region of residence at the time of interview, color/race, and years of schooling at the time of interview.

The other two models test interactions among the main effects: (1) for all observations in the sample; and (2) for cases related to cesarean section. The three sets of interactions tested with these models are: (1) Interaction between age at delivery and parity at delivery. Older women with higher parity might experience higher risks of sterilization, comparing to younger women with lower parity. (2) Interaction between place of delivery and postpartum duration, which verifies whether women in private hospitals have higher chances of getting sterilized during childbirth, comparing to those in public hospitals within zero months after delivery. (3) Interaction between place of delivery and parity at delivery, which tests whether women within public hospitals (SUS) might been having difficulties to get sterilized even with higher parity, comparing to those with lower parity. The following section illustrates the results of the estimated models.

\section{Results}

The sample includes women who were exposed to the risk of sterilization for a total of 88,228 months, resulting in 855 women being sterilized between 2001 and 2007 (Table 1). As a result of the range of categories used for the postpartum duration $(0,1,2,3-6,7-12,13-18,19+)$, the number of person months of exposure to the risk of female sterilization is greater in the 19+ category $(35,632)$. The number of events of sterilization is most concentrated at the moment of delivery (657 events).

>> Table $1<<<$ 
In relation to age at the time of delivery, younger women (15-24) present the most number of births (41.79 percent), resulting in a greater number of person months where they were exposed to the risk of sterilization. Women in the 30-34 age group have a large number of events of sterilization (202), in comparison to their person months of exposure to the risk of sterilization $(13,245)$, resulting in a percentage of 1.53 . Women with two children at delivery have a longer exposure time and more events of sterilization, but lower percentage (0.70).

The majority of the sample is composed of women who gave birth at public hospitals (83.73 percent of all births). Women who delivered their babies at private hospitals present an increased incidence of sterilization (167 events) in relation to their person months of exposure (3,832 months), which represents 4.36 percent.

The distribution of births by region of residence is very similar throughout the varying areas, as a result of the sample design. Women in the Central-West region were exposed to the risk of sterilization for the most number of person months $(20,273)$, while their number of events is the smallest among all regions (123), giving a percentage of only 0.61 . Women in the North present the most number of events of sterilization, in relation to their person months of exposure (1.28 percent).

In terms of color/race, the majority of the sample is composed of births from brown (51.65 percent) and white (33.23 percent) women, corresponding to the most number of person months of exposure to the risk of sterilization, as well as to the highest number of sterilization events. The highest percentage of female sterilization in relation to the number of person months of exposure is among brown women (1.10 percent). Information on educational attainment indicates that most births are from women with four to seven years of schooling (38.85 percent). Women with at least 11 years of schooling have the highest number of events of sterilization in relation to their person months of exposure (1.27 percent).

Table 2 illustrates the exponential function of the coefficients from three hazard models. The first model includes all observations in the sample and indicates that the risk of female sterilization is 93.9 percent lower $\left[(0.0615-1)^{*} 100\right]$ in the month following a birth, compared to the risk of sterilization at the same time of delivery. This risk is even lower in the following postpartum periods. The risk of sterilization increases with age. For instance, women between 30-34 years of age are 3.3 times more likely to get sterilized than women between 15-24 years of age. In terms of parity at delivery, women with two children at the time of a birth present the highest risk of being 
sterilized among all parity groups. In relation to place of delivery, women giving birth with the support of health insurance ("convênio") are 1.4 times more likely to get sterilized than women at public hospitals (SUS). Women at private hospitals have 3.9 higher chances to get sterilized, compared to the reference category. The coefficients of region of residence suggest that women living in the North are 1.4 times more likely to get sterilized than those women in the Southeast. Among women in the Northeast, the odds are 1.3 times higher than the reference category. For the color/race variable, black women are 42.3 percent more likely to get sterilized compared to white women. The coefficients for years of schooling did not present statistical significance.

$\gg>$ Table $2<<<$

Another model was estimated only for observations related to cesarean section delivery. The hazard ratios for interval sterilization $(1+$ months $)$ are even lower than the previous model. This is an indication that sterilization at childbirth has been performed in conjunction with cesarean sections. This pattern seems to be happening all across the country, since the region of residence coefficients lost statistical significance. In the model only for vaginal deliveries, the coefficients for interval sterilization increased considerably, compared to the two previous models. Sterilization at childbirth (zero months) happens in a lower level after a vaginal delivery than after a cesarean delivery, which is probably due to medical recommendations. In terms of parity at delivery, women with two children at the time of a birth present the lowest risk of being sterilized among all parity groups, which is the opposite of the previous models. In relation to place of delivery, women giving birth with the support of health insurance are 79.4 percent less likely to get sterilized than women at public hospitals. The coefficients of region of residence suggest that women living in the North are 1.9 times more likely to get sterilized than those women in the Southeast.

Figure 1 illustrates the cumulative predicted hazard of sterilization from the estimated models by postpartum duration and place of delivery for the 25-29 age group, parity of two children in the Brazilian Southeast. The predicted hazards show much higher changes of getting sterilized for women who have a cesarean section, instead of a vaginal delivery. These chances are higher at childbirth, mostly for women having birth in private hospitals with cesarean section. The cumulative hazards do not increase considerably among women with cesarean section, indicating that most sterilization happens at childbirth and not in interval sterilization.

$>>$ Figure $1<<$ 
Models estimated the effects separated by race groups (white, black, and brown), which suggest higher sterilization at childbirth among black women (data not shown). However, the analysis of cumulative predicted hazards indicates that there are not many cases of black women having birth in private hospitals or with the support of health insurance. Most black women have birth at public hospitals, where the chance to get sterilized is much lower than in private hospitals. The higher chances of getting sterilized among black women are specific to the public sector at higher-order postpartum duration (interval sterilization). The chances of getting sterilized are higher among brown women in private hospitals or with the support of health insurance, compared to white women.

Table 3 illustrates two models that control for interactions among the independent variables. In the first model with all observations, the interactions between age and parity indicate that, among women with two children at the time of delivery, those between 35-49 years of age have the highest risk of getting sterilized (4.5 times more likely), compared to women between 15-24 years of age with two children at the time of delivery. Among women with three children, those with 30-34 years of age are 3.7 more likely to get sterilized than the reference category. Among women with four children or more, those between 35-49 years of age have 4.6 higher risks of getting sterilized, compared to the reference category. This model also indicates higher risks of sterilization for women giving birth with the support of health insurance or at private hospitals at the moment of delivery, compared to women in public hospitals within the same postpartum duration. Women within zero months postpartum are 1.7 times more likely to get sterilized if they have support from health insurance during their delivery (not statistically significant) and 5.3 times more likely if they are in private hospitals, compared to the reference category. Risks of getting sterilized are much lower in the other postpartum categories for all places of delivery. The lowest hazards of female sterilization are estimated for postpartum periods above zero months at private hospitals. Another set of variables evaluates the interaction between place and parity at the time of delivery. At public hospitals, women are less likely to get sterilized if they have four children or more (48.8 percent less likely), compared to women with two children. The other interaction categories between place and parity are not statistically significant. The statistical software dropped several categories, due to few observed cases, which increase standard errors and decrease statistical significance. In terms of region of residence, color/race and years of schooling, the results are similar to the main effects model. Women in the North are 1.3 times more likely to get sterilized than women in the Southeast. Residents in the Northeast are 1.4 times more likely to get sterilized, compared to the reference category. The color/race variable indicates that black women are 39.6 percent more likely to get 
sterilized, compared to white women. Years of schooling did not present significant impacts on the risk of getting sterilized.

\section{>> Table $3<<<$}

The second model of Table 3 has the results for the interactions related to the observations of cesarean section. This model has the same trends as in the model with all women. However, the hazard ratios for the cesarean section model tend to be smaller than the previous model. For instance, women within zero months postpartum are 2.0 times more likely to get sterilized if they are in private hospitals, compared to the reference category, in this subset model, while in the overall model this ratio equals to 5.3. This is an indication that the chances of getting sterilized are high among all women having a cesarean section, independent of their characteristics. Another result is that the impacts of region of residence and color/race lose statistical significance in the model only with cesarean sections. The coefficients for years of schooling also do not have significant impacts on the chances of women getting sterilized.

\section{Discussion}

The analysis estimated the risk of women getting sterilized, taking into account the time of sterilization with data on birth history, similar to previously estimated models. ${ }^{5,40,44,45,49}$ The estimations consider the time of exposure to the risk of female sterilization, as well as the effects of postpartum duration in a longitudinal analysis. Women have a higher risk of getting sterilized following childbirth, despite the regulations of the 1997 family planning law.

One could argue that women are being forced to get sterilized, which might cause regret following the procedure. ${ }^{8,11,26-32}$ However, models indicate that sterilization is greater among older women, those with two children at delivery, as well as in areas of elevated fertility rates (North and Northeast regions). Women who gave birth at private hospitals or with the support of health insurance experience the greatest chances of getting sterilized following a birth. This is an indication that these women may not have been able to get sterilized at public hospitals. Even women with higher-order parity (4+ children) have lower chances of getting sterilized at public hospitals. The family planning law allows sterilization only for people above 25 years of age or with at least two children born alive. This might be a reason that women between 15 and 24 years of age, even with two children ever born, experience low risks of sterilization, compared to the other age groups. 
The family planning law establishes restrictions for female sterilization in public hospitals for surgeries during cesarean deliveries, childbirth, and abortion. However, a large proportion of sterilization has been occurring using health insurance or at private hospitals. Female sterilization is also executed in combination with childbirth and cesarean section. Women might be going to the private sector in order to get sterilized, following an unnecessary cesarean delivery. ${ }^{4,8,21-25,33-37}$ The law could be altered in order to allow female sterilization in conjunction with childbirth, ${ }^{37}$ as a way to attend the demand of women in public hospitals.

Previous studies suggest that higher levels of female sterilization are associated with color/race (higher incidences among black and indigenous) and with lower levels of educational attainment. ${ }^{8}$ ${ }^{18}$ The findings suggest that color/race and years of schooling are not good predictors of the risk of female sterilization, when models take into account the months of exposure to the risk of sterilization. The only remained effect was observed for black women, who have higher chances of getting sterilized than white women. However, the estimated cumulative predicted hazards of sterilization indicate that black women are not subject to the high risks of sterilization at private hospitals and with the support of health insurance. Black women usually have their births at public hospitals, probably due to financial restrictions. As a result, they do present higher risks of sterilization at public hospitals at higher-order postpartum duration (interval sterilization), comparing to white and brown women. This is an evidence that black women are not been able to get sterilized at public hospitals at childbirth, probably due to the regulations of the family planning law. White and brown women experience a higher proportion of births at private hospitals, as well as with the support of health insurance, which result in higher cumulative predicted hazards of sterilization among these women.

The high prevalence of sterilization in private institutions should be a concern for the government. Policies are necessary not only to regulate the public sector, but also to aim better services at private institutions. The government has to implement family planning programs with appropriate health care, guidance, and access to sexual and reproductive health services for women. ${ }^{13-17,24,32,34}$ Access to more options relating to modern contraceptive methods must be provided, as well as appropriate medical follow-ups, which would prevent women from facing the financial and emotional burdens by themselves. 
Table 1. Distribution of births, person months of exposure, and female sterilizations among women delivering live born infants within five years of the survey date, Brazil, January 2001 to July 2007.

\begin{tabular}{|c|c|c|c|c|c|}
\hline Variables & Births & $\begin{array}{c}\text { Births } \\
(\%)\end{array}$ & $\begin{array}{c}\text { Person months } \\
\text { of exposures }\end{array}$ & $\begin{array}{c}\text { Female } \\
\text { sterilizations }\end{array}$ & $\begin{array}{c}\text { Sterilizations / } \\
\text { Exposures (\%) }\end{array}$ \\
\hline Sample size (n) & 3,398 & 100,00 & $\mathbf{8 8 , 2 2 8}$ & 855 & 0.97 \\
\hline \multicolumn{6}{|l|}{ Postpartum duration (months) } \\
\hline 0 & - & - & 12,975 & 657 & 5.06 \\
\hline 1 & - & - & 2,731 & 25 & 0.92 \\
\hline 2 & - & _ & 2,667 & 17 & 0.64 \\
\hline $3-6$ & - & - & 10,001 & 56 & 0.56 \\
\hline $7-12$ & - & - & 13,195 & 26 & 0.20 \\
\hline $13-18$ & - & - & 11,027 & 24 & 0.22 \\
\hline $19+$ & - & - & 35,632 & 50 & 0.14 \\
\hline \multicolumn{6}{|l|}{ Age at delivery (years) } \\
\hline $15-24$ & 1,420 & 41.79 & 40,331 & 230 & 0.57 \\
\hline $25-29$ & 974 & 28.66 & 24,991 & 280 & 1.12 \\
\hline $30-34$ & 586 & 17.25 & 13,245 & 202 & 1.53 \\
\hline $35-49$ & 418 & 12.30 & 9,661 & 143 & 1.48 \\
\hline \multicolumn{6}{|l|}{ Parity at delivery } \\
\hline 2 children & 1,682 & 49.50 & 46,586 & 327 & 0.70 \\
\hline 3 children & 889 & 26.16 & 21,863 & 288 & 1.32 \\
\hline 4 children or more & 827 & 24.34 & 19,779 & 240 & 1.21 \\
\hline \multicolumn{6}{|l|}{ Place of delivery } \\
\hline Public hospital (SUS) & 2,845 & 83.73 & 77,226 & 593 & 0.77 \\
\hline Health insurance ("convênio") & 287 & 8.45 & 7,170 & 95 & 1.32 \\
\hline Private hospital & 266 & 7.83 & 3,832 & 167 & 4.36 \\
\hline \multicolumn{6}{|c|}{ Region of residence at the time of interview } \\
\hline North & 735 & 21.63 & 16,818 & 216 & 1.28 \\
\hline Northeast & 639 & 18.81 & 16,402 & 158 & 0.96 \\
\hline Southeast & 646 & 19.01 & 17,833 & 154 & 0.86 \\
\hline Central-West & 677 & 19.92 & 20,273 & 123 & 0.61 \\
\hline South & 701 & 20.63 & 16,902 & 204 & 1.21 \\
\hline \multicolumn{6}{|l|}{ Color/Race } \\
\hline White ("branca") & 1,129 & 33.23 & 31,377 & 266 & 0.85 \\
\hline Black ("preta") & 340 & 10.01 & 8,873 & 76 & 0.86 \\
\hline Brown ("parda") & 1,755 & 51.65 & 43,123 & 473 & 1.10 \\
\hline Yellow/Asian ("amarela") & 91 & 2.68 & 2,754 & 23 & 0.84 \\
\hline Indigenous ("indígena") & 83 & 2.44 & 2,101 & 17 & 0.81 \\
\hline \multicolumn{6}{|c|}{ Years of schooling at the time of interview } \\
\hline $0-3$ & 692 & 20.36 & 17,325 & 168 & 0.97 \\
\hline $4-7$ & 1,320 & 38.85 & 35,470 & 301 & 0.85 \\
\hline $8-10$ & 699 & 20.57 & 18,668 & 173 & 0.93 \\
\hline $11+$ & 687 & 20.22 & 16,765 & 213 & 1.27 \\
\hline
\end{tabular}

Note: This table was constructed without taking into account the sample design of the survey.

Source: 2006 Brazilian National Survey on Demography and Health of Children and Women (PNDS). 
Table 2. Exponential of coefficients from hazard models (hazard ratios) to estimate the risk of sterilization (main models), Brazil, January 2001 to July 2007.

\begin{tabular}{|c|c|c|c|}
\hline Variables & $\begin{array}{c}\text { All } \\
\text { women }\end{array}$ & $\begin{array}{c}\text { Cesarean } \\
\text { section }\end{array}$ & $\begin{array}{r}\text { Vaginal } \\
\text { delivery }\end{array}$ \\
\hline $\begin{array}{l}\text { Postpartum duration (months) } \\
0\end{array}$ & ref. & ref. & ref. \\
\hline 1 & $\begin{array}{c}0.0615^{* * *} \\
(0.0175)\end{array}$ & $\begin{array}{c}1.51 \mathrm{e}-17 * * * \\
(1.24 \mathrm{e}-18)\end{array}$ & $\begin{array}{c}0.627 \\
(0.205)\end{array}$ \\
\hline 2 & $\begin{array}{c}0.0601 * * * \\
(0.0194)\end{array}$ & $\begin{array}{c}0.000880 * * * \\
(0.000883)\end{array}$ & $\begin{array}{c}0.609 \\
(0.215)\end{array}$ \\
\hline $3-6$ & $\begin{array}{c}0.0608 * * * \\
(0.0127)\end{array}$ & $\begin{array}{c}0.0107 * * * \\
(0.00538)\end{array}$ & $\begin{array}{c}0.549 * * \\
(0.151)\end{array}$ \\
\hline $7-12$ & $\begin{array}{c}0.0204 * * * \\
(0.00647)\end{array}$ & $\begin{array}{c}0.00256^{* * *} \\
(0.00116)\end{array}$ & $\begin{array}{c}0.199 * * * \\
(0.0783)\end{array}$ \\
\hline $13-18$ & $\begin{array}{r}0.0157 * * * \\
(0.00445)\end{array}$ & $\begin{array}{c}0.00700 * * * \\
(0.00353)\end{array}$ & $\begin{array}{l}0.112 * * * \\
(0.0410)\end{array}$ \\
\hline $19+$ & $\begin{array}{l}0.0138 * * * \\
(0.00293)\end{array}$ & $\begin{array}{c}0.00298 * * * \\
(0.00114)\end{array}$ & $\begin{array}{l}0.132 * * * \\
(0.0341)\end{array}$ \\
\hline $\begin{array}{l}\text { Age at delivery (years) } \\
15-24\end{array}$ & ref. & ref. & ref. \\
\hline $25-29$ & $\begin{array}{l}2.307 * * * \\
(0.384)\end{array}$ & $\begin{array}{l}2.355 * * * \\
(0.484)\end{array}$ & $\begin{array}{c}1.373 \\
(0.336)\end{array}$ \\
\hline $30-34$ & $\begin{array}{c}3.257 * * * \\
(0.671)\end{array}$ & $\begin{array}{c}3.124 * * * \\
(0.810)\end{array}$ & $\begin{array}{c}1.265 \\
(0.381)\end{array}$ \\
\hline $35-49$ & $\begin{array}{c}3.545 * * * \\
(0.702)\end{array}$ & $\begin{array}{c}3.117 * * * \\
(0.800)\end{array}$ & $\begin{array}{l}1.025 \\
(0.377) \\
\end{array}$ \\
\hline $\begin{array}{l}\text { Parity at delivery } \\
2 \text { children }\end{array}$ & ref. & ref. & ref. \\
\hline 3 children & $\begin{array}{l}0.762 * \\
(0.107)\end{array}$ & $\begin{array}{c}0.603 * * * \\
(0.0948)\end{array}$ & $\begin{array}{c}2.016^{* * * *} \\
(0.505)\end{array}$ \\
\hline 4 children or more & $\begin{array}{l}0.583 * * * \\
(0.115) \\
\end{array}$ & $\begin{array}{c}0.526^{* * *} \\
(0.105) \\
\end{array}$ & $\begin{array}{l}1.978 * * \\
(0.555)\end{array}$ \\
\hline $\begin{array}{l}\text { Place of delivery } \\
\text { Public hospital (SUS) }\end{array}$ & ref. & ref. & ref. \\
\hline Health insurance ("convênio") & $\begin{array}{l}1.429 * \\
(0.294)\end{array}$ & $\begin{array}{c}0.889 \\
(0.179)\end{array}$ & $\begin{array}{l}0.206^{*} \\
(0.185)\end{array}$ \\
\hline Private hospital & $\begin{array}{c}3.916 * * * \\
(0.765)\end{array}$ & $\begin{array}{c}2.199 * * * \\
(0.352)\end{array}$ & $\begin{array}{l}1.815 \\
(0.979)\end{array}$ \\
\hline Region of residence at the time of interview & & & \\
\hline North & $\begin{array}{l}1.354^{*} \\
(0.222)\end{array}$ & $\begin{array}{c}1.077 \\
(0.197)\end{array}$ & $\begin{array}{l}1.886^{*} \\
(0.714)\end{array}$ \\
\hline Northeast & $\begin{array}{l}1.335^{*} \\
(0.209)\end{array}$ & $\begin{array}{c}1.252 \\
(0.216)\end{array}$ & $\begin{array}{c}1.707 \\
(0.573)\end{array}$ \\
\hline Southeast & ref. & ref. & ref. \\
\hline South & $\begin{array}{c}0.752 \\
(0.138)\end{array}$ & $\begin{array}{c}0.747 \\
(0.138)\end{array}$ & $\begin{array}{c}0.529 \\
(0.219)\end{array}$ \\
\hline Central-West & $\begin{array}{c}1.239 \\
(0.190)\end{array}$ & $\begin{array}{c}1.059 \\
(0.166)\end{array}$ & $\begin{array}{c}1.224 \\
(0.477)\end{array}$ \\
\hline $\begin{array}{l}\text { Color/Race } \\
\text { White ("branca") }\end{array}$ & ref. & ref. & ref. \\
\hline Black ("preta") & $\begin{array}{l}1.423 * \\
(0.287)\end{array}$ & $\begin{array}{c}1.227 \\
(0.284)\end{array}$ & $\begin{array}{c}1.391 \\
(0.474)\end{array}$ \\
\hline Brown ("parda") & $\begin{array}{l}1.200 \\
(0.165)\end{array}$ & $\begin{array}{l}1.107 \\
(0.144)\end{array}$ & $\begin{array}{c}1.202 \\
(0.314)\end{array}$ \\
\hline Yellow/Asian ("amarela") & $\begin{array}{c}1.038 \\
(0.332)\end{array}$ & $\begin{array}{c}1.026 \\
(0.315)\end{array}$ & $\begin{array}{c}0.295 \\
(0.291)\end{array}$ \\
\hline
\end{tabular}




\begin{tabular}{|c|c|c|c|}
\hline Indigenous ("indígena") & $\begin{array}{c}1.551 \\
(0.789)\end{array}$ & $\begin{array}{c}0.581 \\
(0.204)\end{array}$ & $\begin{array}{l}3.373^{*} \\
(2.159)\end{array}$ \\
\hline $\begin{array}{l}\text { Years of schooling at the time of interview } \\
0-3 \\
4-7\end{array}$ & $\begin{array}{l}0.936 \\
(0.173) \\
\text { ref. }\end{array}$ & $\begin{array}{l}0.818 \\
(0.201) \\
\text { ref. }\end{array}$ & $\begin{array}{l}1.370 \\
(0.370) \\
\text { ref. }\end{array}$ \\
\hline $\begin{array}{l}8-10 \\
11+\end{array}$ & $\begin{array}{c}1.069 \\
(0.167) \\
1.034 \\
(0.163) \\
\end{array}$ & $\begin{array}{c}0.921 \\
(0.171) \\
0.828 \\
(0.147) \\
\end{array}$ & $\begin{array}{c}1.098 \\
(0.298) \\
1.387 \\
(0.455)\end{array}$ \\
\hline $\begin{array}{l}\text { Model statistics } \\
\text { Log likelihood } \\
\text { Degrees of freedom } \\
\text { Likelihood Ratio Chi-Square }\end{array}$ & $\begin{array}{c}-2,444.0 \\
24 \\
2,238.8 * * * \\
\end{array}$ & $\begin{array}{c}-1,110.5 \\
24 \\
2,434.8 * * * \\
\end{array}$ & $\begin{array}{c}-996.0 \\
24 \\
282.9^{* * *} \\
\end{array}$ \\
\hline $\begin{array}{l}\text { Survey statistics } \\
\text { Number of strata } \\
\text { Number of primary sampling units (PSUs) } \\
\text { F-test }\end{array}$ & $\begin{array}{c}10 \\
994 \\
\mathrm{~F}(24 ; 961)= \\
48.5^{* * *}\end{array}$ & $\begin{array}{c}10 \\
718 \\
\mathrm{~F}(24 ; 685)= \\
14,044.6^{* * *}\end{array}$ & $\begin{array}{c}10 \\
789 \\
\mathrm{~F}(24 ; 756)= \\
8.9 * * *\end{array}$ \\
\hline Number of observations & 17,376 & 5,034 & 12,342 \\
\hline
\end{tabular}

Note: Standard errors within parentheses. The log likelihood and the likelihood ratio chi-square were estimated without taking into account the sample design of the survey. All other statistics were estimated taking into account the sample design of the survey. $* * *$ Significant at $\mathrm{p}<0.01 ; * *$ Significant at $\mathrm{p}<0.05 ; *$ Significant at $\mathrm{p}<0.1$.

Source: 2006 Brazilian National Survey on Demography and Health of Children and Women (PNDS). 
Figure 1. Cumulative predicted hazard of sterilization from models in Table 2 by postpartum duration and place of delivery for 25-29 age group, parity of two children, Brazilian Southeast, January 2001 to July 2007.

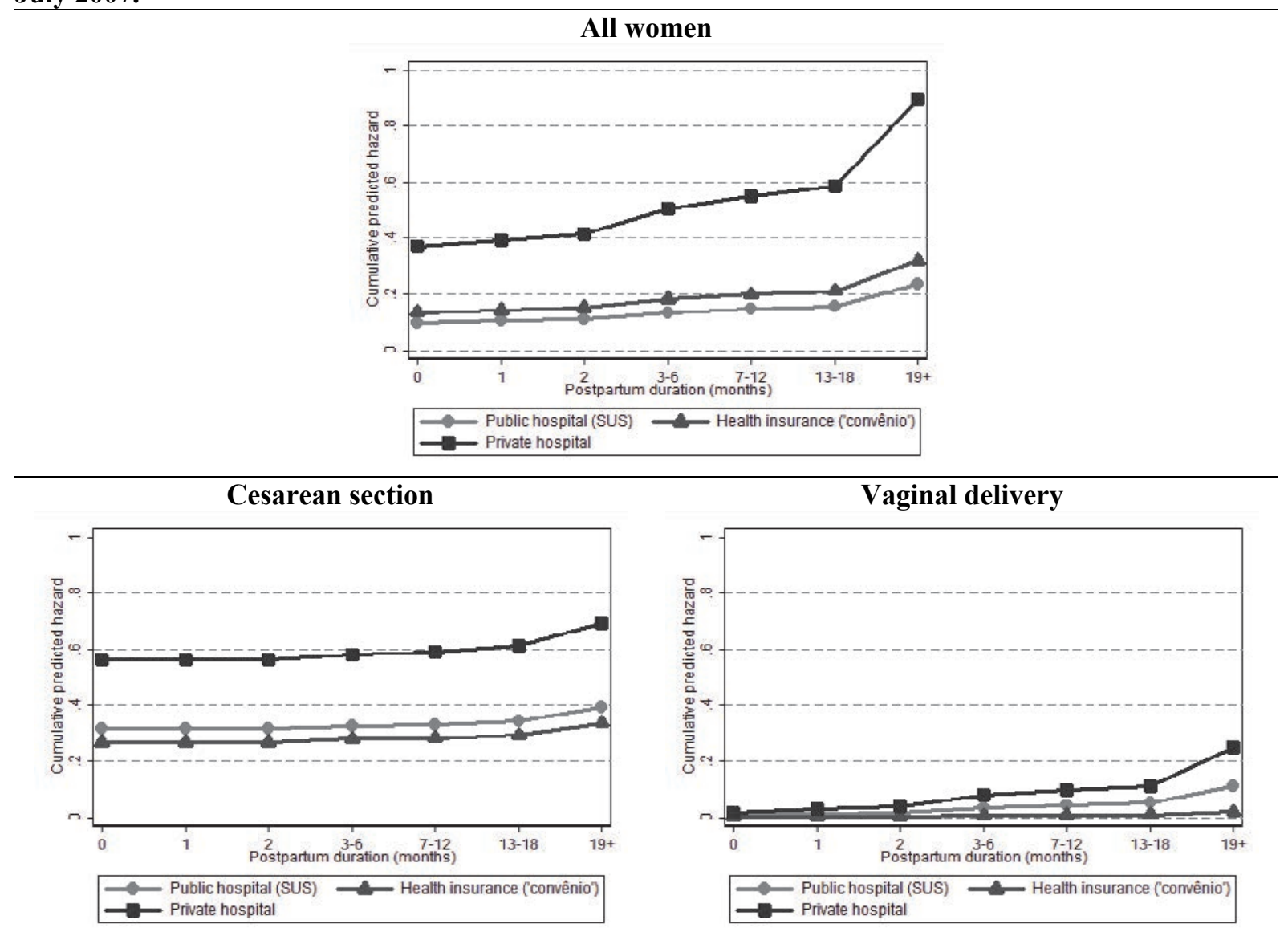

Note: The cumulative predicted hazards were estimated taking into account the sample design of the survey. The hazards represent the mean across the different color/race and years of schooling categories.

Source: 2006 Brazilian National Survey on Demography and Health of Children and Women (PNDS). 
Table 3. Exponential of coefficients from a hazard model (hazard ratios) to estimate the risk of sterilization (interaction models), Brazil, January 2001 to July 2007.

\begin{tabular}{|c|c|c|}
\hline Variables & $\begin{array}{c}\text { All } \\
\text { women }\end{array}$ & $\begin{array}{c}\text { Cesarean } \\
\text { section }\end{array}$ \\
\hline $\begin{array}{l}\text { Age at delivery * Parity at delivery } \\
\text { Age } 15-24,2 \text { children }\end{array}$ & ref. & ref. \\
\hline Age $25-29,2$ children & $\begin{array}{c}2.777 * * * \\
(0.654)\end{array}$ & $\begin{array}{c}2.957 * * * \\
(0.769)\end{array}$ \\
\hline Age $30-34,2$ children & $\begin{array}{c}4.189 * * * \\
(1.184)\end{array}$ & $\begin{array}{c}3.384 * * * \\
(0.967)\end{array}$ \\
\hline Age $35-49,2$ children & $\begin{array}{c}4.513 * * * \\
(1.260)\end{array}$ & $\begin{array}{c}3.794 * * * \\
(1.208)\end{array}$ \\
\hline Age $15-24,3$ children & $\begin{array}{c}1.071 \\
(0.393)\end{array}$ & $\begin{array}{c}1.057 \\
(0.444)\end{array}$ \\
\hline Age $25-29,3$ children & $\begin{array}{c}2.406 * * \\
(0.858)\end{array}$ & $\begin{array}{c}2.136^{* *} \\
(0.810)\end{array}$ \\
\hline Age $30-34,3$ children & $\begin{array}{c}3.715 * * * \\
(1.481)\end{array}$ & $\begin{array}{c}3.510 * * * \\
(1.640)\end{array}$ \\
\hline Age $35-49,3$ children & $\begin{array}{l}3.034 * * * \\
(1.292)\end{array}$ & $\begin{array}{l}2.830 * * \\
(1.330)\end{array}$ \\
\hline Age $15-24,4$ children or more & $\begin{array}{c}2.267 * * \\
(0.925)\end{array}$ & $\begin{array}{c}1.591 \\
(0.756)\end{array}$ \\
\hline Age $25-29,4$ children or more & $\begin{array}{c}3.312 * * * \\
(1.248)\end{array}$ & $\begin{array}{c}3.229 * * * \\
(1.309)\end{array}$ \\
\hline Age $30-34,4$ children or more & $\begin{array}{c}3.290 * * * \\
(1.276)\end{array}$ & $\begin{array}{c}3.303 * * \\
(1.599)\end{array}$ \\
\hline Age $35-49,4$ children or more & $\begin{array}{c}4.558 * * * \\
(1.525)\end{array}$ & $\begin{array}{l}3.110 * * \\
(1.380)\end{array}$ \\
\hline $\begin{array}{l}\text { Place of delivery * Postpartum duration } \\
\text { Public hospital (SUS), } 0 \text { months }\end{array}$ & ref. & ref. \\
\hline Public hospital (SUS), 1 month & $\begin{array}{l}0.103 * * * \\
(0.0302)\end{array}$ & $\begin{array}{l}3.32 \mathrm{e}-18 * * * \\
(3.96 \mathrm{e}-19)\end{array}$ \\
\hline Public hospital (SUS), 2 months & $\begin{array}{c}0.0952 * * * \\
(0.0327)\end{array}$ & $\begin{array}{c}0.00158 * * * \\
(0.00160)\end{array}$ \\
\hline Public hospital (SUS), 3-6 months & $\begin{array}{c}0.0983 * * * \\
(0.0229)\end{array}$ & $\begin{array}{c}0.0136 * * * \\
(0.00901)\end{array}$ \\
\hline Public hospital (SUS), 7-12 months & $\begin{array}{c}0.0346 * * * \\
(0.0113)\end{array}$ & $\begin{array}{c}0.00454 * * * \\
(0.00218)\end{array}$ \\
\hline Public hospital (SUS), 13-18 months & $\begin{array}{c}0.0267 * * * \\
(0.00786)\end{array}$ & $\begin{array}{c}0.0126 * * * \\
(0.00646)\end{array}$ \\
\hline Public hospital (SUS), 19+ months & $\begin{array}{l}0.0220 * * * \\
(0.00516)\end{array}$ & $\begin{array}{c}0.00391 * * * \\
(0.00190)\end{array}$ \\
\hline Health insurance ("convênio"), 0 months & $\begin{array}{l}1.654 \\
(0.942)\end{array}$ & $\begin{array}{l}0.745 \\
(0.411)\end{array}$ \\
\hline Health insurance ("convênio"), 1 month & $\begin{array}{c}5.11 \mathrm{e}-18 * * * \\
(3.07 \mathrm{e}-18)\end{array}$ & $\begin{array}{c}2.03 \mathrm{e}-18 * * * \\
(1.19 \mathrm{e}-18)\end{array}$ \\
\hline Health insurance ("convênio"), 2 months & $\begin{array}{c}0.0234 * * * \\
(0.0270)\end{array}$ & $\begin{array}{c}2.12 \mathrm{e}-18^{* * *} \\
(1.21 \mathrm{e}-18)\end{array}$ \\
\hline Health insurance ("convênio"), 3-6 months & $\begin{array}{c}0.0193 * * * \\
(0.0172)\end{array}$ & $\begin{array}{c}0.00946 * * * \\
(0.00837)\end{array}$ \\
\hline Health insurance ("convênio"), 7-12 months & $\begin{array}{c}5.19 \mathrm{e}-18 * * * \\
(3.03 \mathrm{e}-18)\end{array}$ & $\begin{array}{c}2.06 \mathrm{e}-18 * * * \\
(1.19 \mathrm{e}-18)\end{array}$ \\
\hline Health insurance ("convênio"), 13-18 months & $\begin{array}{c}5.12 \mathrm{e}-18 * * * \\
(3.00 \mathrm{e}-18)\end{array}$ & $\begin{array}{c}2.03 \mathrm{e}-18 * * * \\
(1.18 \mathrm{e}-18)\end{array}$ \\
\hline Health insurance ("convênio"), 19+ months & $\begin{array}{c}0.00349 * * * \\
(0.00324)\end{array}$ & $\begin{array}{c}0.00165 * * * \\
(0.00153)\end{array}$ \\
\hline Private hospital, 0 months & $\begin{array}{l}5.324 * * * \\
(1.520)\end{array}$ & $\begin{array}{l}1.956^{* * *} \\
(0.426)\end{array}$ \\
\hline Private hospital, 1 month & $\begin{array}{c}7.23 \mathrm{e}-18^{* * *} \\
(2.41 \mathrm{e}-18)\end{array}$ & $\begin{array}{c}2.78 \mathrm{e}-18 * * * \\
(7.20 \mathrm{e}-19)\end{array}$ \\
\hline Private hospital, 2 months & $7.24 \mathrm{e}-18 * * *$ & $2.80 \mathrm{e}-18 * * *$ \\
\hline
\end{tabular}




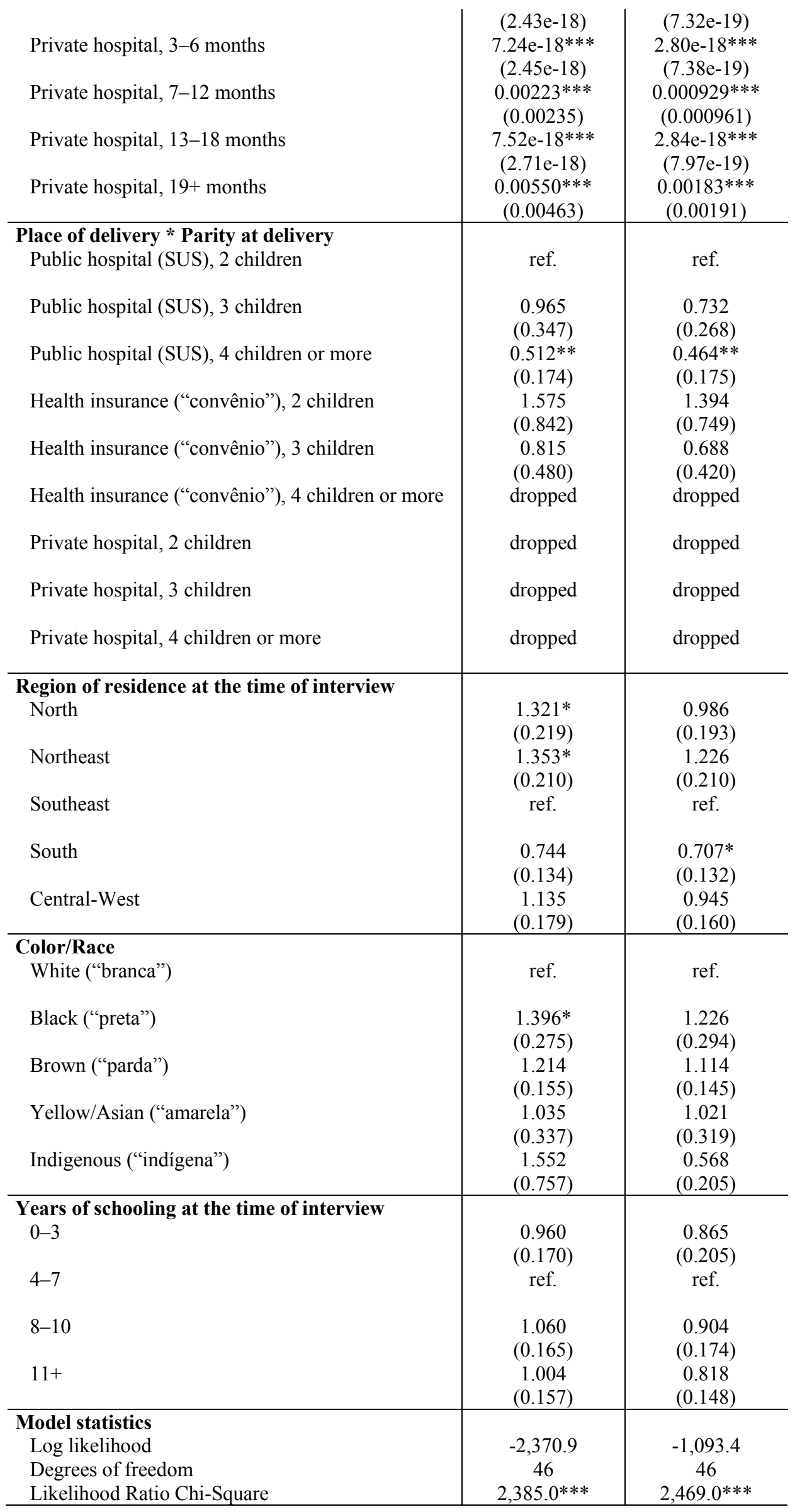




\begin{tabular}{l|c|c}
\hline Survey statistics & & \\
Number of strata & 10 & 10 \\
Number of primary sampling units (PSUs) & 994 & 718 \\
F-test & $\mathrm{F}(46 ; 939)=$ & $\mathrm{F}(46 ; 663)=$ \\
& $5,464.5^{* * *}$ & $15,021.4^{* * *}$ \\
\hline Number of observations & 17,376 & 5,034 \\
\hline
\end{tabular}

Note: Standard errors within parentheses. The log likelihood and the likelihood ratio chi-square were estimated without taking into account the sample design of the survey. All other statistics were estimated taking into account the sample design of the survey. $* * *$ Significant at $\mathrm{p}<0.01 ; * *$ Significant at $\mathrm{p}<0.05 ; *$ Significant at $\mathrm{p}<0.1$.

Source: 2006 Brazilian National Survey on Demography and Health of Children and Women (PNDS). 


\section{References}

1. IBGE. Censo Demográfico 2010: Resultados Gerais da Amostra. Rio de Janeiro: Instituto Brasileiro de Geografia e Estatística (IBGE); 2012.

2. Potter JE, Schmertmann CP, Cavenaghi SM. Fertility and development: evidence from Brazil. Demography. 2002; 39:739-61.

3. Potter JE, Schmertmann CP, Assunção RM, Cavenaghi SM. Mapping the timing, pace, and scale of the fertility transition in Brazil. Population and Development Review. 2010; 36:283-307.

4. Berquó E, Garcia S, Lago T, editors. PNDS 2006, Pequisa Nacional de Demografia e Saúde da Criança e da Mulher: Relatório. Brasília: Ministério da Saúde; 2008.

5. Leone T, Hinde A. Sterilization and union instability in Brazil. Journal of Biosocial Science. 2005; 37:459-69.

6. Perpétuo IHO. Contracepção e declínio da fecundidade na Região Nordeste. Revista Brasileira de Estudos de População. 1998; 15:43-56.

7. Perpétuo IHO, Wajnman S. Socioeconomic correlates of female sterilization in Brazil. In: Cosio-Zavala ME, editor. Poverty, Fertility and Family Planning. Paris: CICRED; 2003. p. 311-33.

8. Perpétuo IHO, Wong LR. Desigualdade socioeconômica na utilização de métodos anticoncepcionais no Brasil: uma análise comparativa com base nas PNDS 1996 e 2006. In: Brasil, editor. Pesquisa Nacional de Demografia e Saúde da Criança e da Mulher - PNDS 2006: Dimensões do Processo Reprodutivo e da Saúde da Criança. Brasília: Ministério da Saúde; Centro Brasileiro de Análise e Planejamento (CEBRAP); 2009. p. 87-104.

9. Janowitz B, Higgins JE, Rodrigues W, Arruda JM, Smith JB, Morris L. Sterilization in the Northeast of Brazil. Soc Sci Med. 1985; 20:215-21.

10. Potter JE. The persistence of outmoded contraceptive regimes: the cases of Mexico and Brazil. Population and Development Review. 1999; 25:703-39.

11. Vieira EM. O arrependimento após a esterilização cirúrgica e o uso das tecnologias reprodutivas. Revista Brasileira de Ginecologia e Obstetrícia. 2007; 29:225-9.

12. Fonseca Sobrinho D. Estado e População: uma História do Planejamento Familiar no Brasil. Rio de Janeiro: Editora Rosa dos Tempos; Fundo de População das Nações Unidas (FNUAP); 1993. 13. Bilac ED, Rocha MIB, editors. Saúde Reprodutiva na América Latina e no Caribe: Temas e Problemas. Campinas: Programa Latinoamericano de Actividades en Población (PROLAP); Associação Brasileira de Estudos de População (ABEP); Núcleo de Estudos de População (NEPO) da Universidade Estadual de Campinas (UNICAMP); 1998.

14. Giffin K, Costa SH. Questões da Saúde Reprodutiva. Rio de Janeiro: Editora Fiocruz; 1999. 15. Miranda-Ribeiro P, Simão AB. Qualificando os Números: Estudos sobre Saúde Sexual e Reprodutiva no Brasil. Belo Horizonte: Associação Brasileira de Estudos Populacionais (ABEP); Fundo de População das Nações Unidas (UNFPA); 2009.

16. Schor N, Ferreira AF, Machado VL, França AP, Pirotta KCM, Alvarenga AT, et al. Mulher e anticoncepção: conhecimento e uso de métodos anticoncepcionais. Cadernos de Saúde Pública. 2000; 16:377-84.

17. Vieira EM, Souza L. Access to surgical sterilization through the National Health System, Ribeirão Preto, Southeastern Brazil. Revista de Saúde Pública. 2009; 43:398-404.

18. Amorim FA, Cavenaghi SM, Alves JED. Mudanças recentes no uso de métodos contraceptivos no Brasil e na Colômbia: com especial menção à esterilização masculina e feminina. In: Wong LR, editor. Población y Salud Sexual y Reproductiva en América Latina. Rio de Janeiro: Asociación Latinoamericana de Población (ALAP); 2008. p. 101-30.

19. Cavenaghi S, Alves JED. Fertility and contraception in Latin America: historical trends, recent patterns. In: Cavenaghi S, editor. Demographic Transformations and Inequalities in Latin America: Historical Trends and Recent Patterns. Rio de Janeiro: Latin American Population Association (ALAP); 2009.

20. Lei n. 9.263, de 12 de janeiro de 1996. Regula o parágrafo 7 do artigo 226 da Constituição Federal, que trata do planejamento familiar, estabelece penalidades e dá outras providências, (1996). 
21. Barbosa RM, Knauth DR. Esterilização feminina, AIDS e cultura médica: os casos de São Paulo e Porto Alegre, Brasil. Cadernos de Saúde Pública. 2003; 19:S365-S76.

22. Berquó E. Ainda a questão da esterilização feminina no Brasil. In: Giffin K, Costa SH, editors. Questões de Saúde Reprodutiva. Rio de Janeiro: Editora Fiocruz; 1999. p. 113-26.

23. Berquó E, Cavenaghi S. Direitos reprodutivos de mulheres e homens face à nova legislação brasileira sobre esterilização voluntária. Cadernos de Saúde Pública. 2003; 19:S441-S53.

24. Carvalho LEC, Osis MJD, Cecatti JG, Bento SF, Manfrinati MB. Esterilização cirúrgica voluntária na Região Metropolitana de Campinas, São Paulo, Brasil, antes e após sua regulamentação. Cadernos de Saúde Pública. 2007; 23:2906-16.

25. Molina A. Laqueadura tubária: situação nacional, internacional e efeitos colaterais. In: Giffin K, Costa SH, editors. Questões da Saúde Reprodutiva. Rio de Janeiro: Editora Fiocruz; 1999. p. 127-45.

26. Cunha ACR, Wanderley MS, Garrafa V. Fatores associados ao futuro reprodutivo de mulheres desejosas de gestação após ligadura tubária. Revista Brasileira de Ginecologia e Obstetrícia. 2007; 29:230-4.

27. Curtis KM, Mohllajee AP, Peterson HB. Regret following female sterilization at a young age: a systematic review. Contraception. 2006; 73:205-10.

28. Fernandes AMS, Arruda MS, Palhares MAR, Benetti Júnior ND, Moreira CM. Seguimento de mulheres laqueadas arrependidas em serviço público de esterilidade conjugal. Revista Brasileira de Ginecologia e Obstetrícia. 2001; 23:69-73.

29. Hopkins K. Getting sterilized in Brazil: stories of sucess and failure. In: Miranda-Ribeiro P, Simão AB, editors. Qualificando os Números: Estudos sobre Saúde Sexual e Reprodutiva no Brasil. Belo Horizonte: Associação Brasileira de Estudos Populacionais (ABEP); Fundo de População das Nações Unidas (UNFPA); 2009. p. 167-83.

30. Ludermir AB, Machado KMM, Costa AM, Alves SV, Araújo TVB. Tubal ligation regret and related risk factors: findings from a case-control study in Pernambuco state, Brazil. Cadernos de Saúde Pública. 2009; 25:1361-8.

31. Machado KMM, Ludermir AB, Costa AM. Changes in famly structure and regret following tubal sterilization. Cadernos de Saúde Pública. 2005; 21:1768-77.

32. Vieira EM, Fábio SV, Gueleri W, Picado MP, Yoshinaga E, Souza L. Características dos candidatos à esterilização cirúrgica e os fatores associados ao tipo de procedimento. Cadernos de Saúde Pública. 2005; 21:1785-91.

33. Caetano AJ, Potter JE. Politics and female sterilization in Northeast Brazil. Population and Development Review. 2004; 30:79-108.

34. Costa NDL, Paes NA, Ramos PCF, Formiga MCC. Desejo, intenção e comportamento na saúde reprodutiva: a prática da cesárea em cidade do Nordeste do Brasil. Revista Brasileira de Ginecologia e Obstetrícia. 2006; 28:388-96.

35. Lacerda MA, Miranda-Ribeiro P, Caetano AJ, Machado CJ. Mensuração e perfis de demanda insatisfeita por contracepção nos municípios de Belo Horizonte e Recife, 2002. Revista Brasileira de Estudos de População. 2005; 22:113-29.

36. Osis MJD, Carvalho LEC, Cecatti JG, Bento SF, Pádua KS. Atendimento à demanda pela esterilização cirúrgica na Região Metropolitana de Campinas, São Paulo, Brasil: percepção de gestores e profissionais dos serviços públicos de saúde. Cadernos de Saúde Pública. 2009; 25:62534.

37. Potter JE, Perpétuo IHO, Berquó E, Hopkins K, Leal OF, Formiga MCC, et al. Frustrated demand for postpartum female sterilization in Brazil. Contraception. 2003; 67:385-90.

38. Caetano AJ. Esterilização cirúrgica feminina no Brasil, 2000 a 2006: Aderência à lei de planejamento familiar e demanda frustrada. Revista Brasileira de Estudos de População. 2014; 31:309-31.

39. Osis MJD, Faúndes A, Sousa MH, Duarte GA, Bailey P. Fecundidade e história reprodutiva de mulheres laqueadas e não laqueadas de Campinas, São Paulo, Brasil. Cadernos de Saúde Pública. 2003; 19:1399-404. 
40. Godecker AL, Thomson E, Bumpass LL. Union status, marital history and female contraceptive sterilization in the United States. Family Planning Perspectives. 2001; 33:25-41+9.

41. Minella LS. Esterilização feminina: temáticas e abordagens em periódicos científicos no Brasil (2000-2010). In: ABEP, editor. 18th meeting of the Brazilian Association of Population Studies; November, 19-23; Águas de Lindóia: Associação Brasileira de Estudos Populacionais (ABEP); 2012.

42. Blossfeld HP, Golsch K, Rohwer G. Techniques of Event History Modeling using Stata: New Approaches to Causal Analysis. Mahwah: Lawrence Erlbaum Associates, Inc., Publishers; 2007.

43. Blossfeld HP, Rohwer G. Techniques of Event History Modeling: New Approaches to Causal Analysis. Mahwah: Lawrence Erlbaum Associates, Inc., Publishers; 2002.

44. Leon JG, Potter JE. Modelling the inverse association between breastfeeding and contraceptive use. Population Studies. 1989; 43:69-93.

45. Steele F. A discrete-time multilevel mixture model for event history data with long-term survivors, with an application to an analysis of contraceptive sterilization in Bangladesh. Lifetime Data Analysis. 2003; 9:155-74.

46. Singer JD, Willett JB. Applied Longitudinal Data Analysis: Modeling Change and Event Occurrence. New York: Oxford University Press; 2003.

47. Oliveira MC. Homens e contracepção: Análise estatística de dados qualitativos. Revista Brasileira de Estudos de População. 2003; 20:63-77.

48. Oliveira MC, Bilac ED, Muszkat M. Homens e anticoncepção: Um estudo sobre duas gerações masculinas das "camadas médias" paulistanas. In: Miranda-Ribeiro P, Simão AB, editors. Qualificando os Números: Estudos sobre Saúde Sexual e Reprodutiva no Brasil. Belo Horizonte: Associação Brasileira de Estudos Populacionais (ABEP); Fundo de População das Nações Unidas (UNFPA); 2009. p. 275-311.

49. White K, Potter JE. Reconsidering racial/ethnic differences in sterilization in the Unites States. Contraception. 2014; 89:550-6. 